\title{
Conflicto de intereses en el contexto societario: regulación colombiana y derecho comparado*
}

\author{
Conflict of interests in corporate law: colombian regulations \\ and comparative law \\ Conflito de interesses no contexto societário: regulação colombiana \\ e direito comparado
}

\section{Carlos Andrés Arcila Salazar ${ }^{* \star}$}

FECHA DE RECEPCIÓN: 1 de NOVIEMBRE DE 2016. FeCHA DE ACEPTACIÓN: 11 DE ENERO DE 2017

Para citar este artículo: Arcila, C. A. (2017). Conflicto de intereses en el contexto societario: regulación colombiana y derecho comparado. Estudios Socio-Jurídicos, 19(2), 157-196. Doi: xxxxxxxxx

\section{RESUMEN}

Este documento tiene como propósito ilustrar sobre la regulación colombiana en relación con el conflicto de intereses en el contexto societario, de la mano de la doctrina nacional, y el derecho comparado, para entender las actuales discusiones en esta materia y ver hacia dónde debe enfocarse el análisis de las futuras reformas legislativas.

Palabras clave: conflicto, intereses, contexto societario, derecho comparado.

* El presente documento hace parte de la investigación realizada para el trabajo de grado titulado $E l$ conflicto de intereses en el régimen de administradores de sociedades comerciales, presentado en junio de 2016 a la Maestría en Derecho Empresarial, Facultad de Humanidades y Ciencias Sociales de la Pontificia Universidad Javeriana, Cali (Colombia), para optar al título de Magíster en Derecho Empresarial.

** Abogado de la Universidad Libre, Pereira (Colombia), Especialista en Derecho Comercial y en Legislación Tributaria de la Universidad Pontificia Bolivariana, Medellín (Colombia) y Magíster en Derecho Empresarial de la Pontificia Universidad Javeriana, Cali (Colombia). Intendente Regional de la Superintendencia de Sociedades en Cali y Profesor del Departamento de Ciencia Jurídica y Política de la Pontificia Universidad Javeriana, Cali (Colombia). Correo electrónico: carlos.arcila@javerianacali.edu.co 


\section{ABSTRACT}

This paper has the goal of discussing the colombian regulations regarding conflict of interests in corporate law based on national doctrine, and comparative law, to understand the current discussions in this matter and to see what the analysis of the future legislative reforms must focus on.

Keywords: conflict, interests, corporate law, comparative law.

\section{RESUMO}

Este documento tem como propósito ilustrar sobre a regulação colombiana em relação com o conflito de interesses no contexto societário, da mão da doutrina nacional, e o direito comparado, para entender as atuais discussões nesta matéria e ver para onde deve se enfocar a análise das futuras reformas legislativas.

Palavras-chave: conflito, interesses, contexto societário, direito comparado. 


\section{Introducción}

Un tema de singular importancia en el derecho societario corresponde al conflicto de intereses ${ }^{1}$, donde la legislación sobre la materia tiene como finalidad hacer prevalecer el interés de la sociedad, buscado dar respuesta jurídica a los denominados "problemas de agencia" (agency problems), es decir, "las dificultades que surgen cuando el bienestar de una de las partes, denominada el mandante (principal), depende de las acciones adelantadas por un tercero, denominado el mandatario o agente (agent)" (Reyes, 2013a, p. 41). Estos conflictos nacen cuando "debido a la existencia de asimetría de información en esta interrelación, los incentivos del agente varían en detrimento del interés del principal y en provecho de su propio interés" (Delvasto, 2007, p. 308).

Teniendo en cuenta que los intereses son un elemento determinante en la constitución y desarrollo de las sociedades, en el análisis económico del derecho societario se han identificado tres problemas derivados de la agencia y cuya solución va encaminada a generar una operación eficiente de la sociedad, así como una efectiva obtención de recursos por parte de los socios o accionistas: 1) el conflicto que existe entre los asociados y los administradores; 2) el antagonismo que se presenta entre los asociados mayoritarios y los minoritarios y 3) la contraposición de intereses de la sociedad y los terceros interesados.

De los problemas en mención, es de especial interés el que ocurre entre los asociados y los administradores de la compañía, toda vez que estos últimos, en muchas ocasiones, pueden buscar satisfacer sus propios intereses o los de una persona en cuyo interés actúan, desnaturalizando la función para la que se constituye una sociedad. Esta situación coloca a los administradores en un conflicto entre los intereses de la sociedad -y de los asociados-y los propios. Al respecto, Cuif (2007) manifiesta lo siguiente:

1 Para efectos del presente trabajo se utilizará la forma "conflicto de intereses", habida consideración que al margen de cuántas personas intervienen en una situación conflictiva, estamos en presencia de una sola y no de varias, por ello la expresión "conflicto", en singular y no en plural. Por otra parte, en un "conflicto" no existe un único interés, pues se encuentran en contraposición varios intereses, independientemente que estos se radiquen en una o más personas, de allí que se acoja el término "intereses", en plural y no en singular. 
[...] la gestión de la sociedad es igualmente una ocasión de conflicto de intereses. El dirigente social estará tentado de abusar de su posición con el fin de satisfacer sus intereses personales en detrimento del interés social, así, el administrador se encuentra en posible conflicto de intereses (p. 67).

En Colombia, la Ley 222 de 1995, por la cual se modifica el Libro II del Código de Comercio, se expide un nuevo régimen de procesos concursales y se dictan otras disposiciones, corresponde a la primera norma en materia societaria que modificó sustancialmente el Decreto 410 de 1971, por el cual se expide el Código de Comercio. Dentro del conjunto de cambios o adiciones importantes, encontramos lo correspondiente al régimen de administradores de sociedades comerciales, reformas consagradas en los artículos 22 al 25, en los que se incluyó, como desarrollo del deber genérico de lealtad, el deber específico de los administradores, consistente en que éstos deben abstenerse de participar en actos que impliquen conflicto de intereses ${ }^{2}$.

Las disposiciones legales mencionadas no definieron el contenido normativo del "conflicto de intereses", dando lugar a un "concepto jurídico indeterminado", es decir, el que se usa en una norma para indicar de manera imprecisa un supuesto de hecho, tal como ocurre con el "interés público", la "urgencia", la "protección adecuada", etc 3 .

La ventaja de los "conceptos jurídicos indeterminados" para la función legislativa es bastante evidente: permiten abarcar una gran cantidad de

2 Los socios o accionistas también pueden generar conductas que constituyen un conflicto de intereses cuando en procura de un beneficio propio o en favor de un tercero, autoricen expresamente la realización de transacciones que perjudiquen los intereses de la sociedad, de los asociados o de terceros. Este tipo de conflictos se presentan, típicamente, en la toma de decisiones sociales en el ámbito de la junta de socios o asamblea general de accionistas y se encuadran en el marco general de las relaciones entre mayorías y minorías. Un examen sobre la responsabilidad de los socios o accionistas que autorizan la celebración de un acto o contrato en conflicto de intereses puede verse en Gil (2015). Sobre el derecho de voto y el conflicto de intereses, ver Gaviria (2004).

3 El derecho no sólo se integra con "conceptos jurídicos determinados" (delimitados en su aplicación), sino que también se compone de "conceptos jurídicos indeterminados", es decir, aquellos que "se consignan en los diferentes cuerpos normativos, formulados sin distinguir o fijar los parámetros de aplicación y pueden considerarse concepciones jurídicas que tienen en algún nivel ambigüedad e imprecisión y, por tal, que pueden admitir aplicaciones diferentes, o ser perfilados de forma distinta, lo que llevará a generar incertidumbre e incluso confusión y, consecuentemente, motivos de duda a la hora de fijar su significado jurídico" (Nuñez, 2013, p. 20). 
situaciones, sin necesidad de determinar claramente sus detalles o en qué consisten. El principal problema de estos conceptos es de interpretación, toda vez que no existen varias alternativas de solución sino una sola, a la que hay que llegar interpretando el caso concreto ${ }^{4}$, lo que exige acometer un complejo análisis, particularmente probatorio, para establecer en el tema objeto de estudio si la conducta del administrador ha afectado del deber de lealtad, es decir, si se ha presentado una situación de "conflicto de intereses".

En el anterior orden de ideas, la pregunta que plantea el presente documento es: ¿la utilización en la legislación societaria colombiana del conflicto de intereses como un "concepto jurídico indeterminado" garantiza de mejor manera la gestión de los administradores?

Para responder esta pregunta, este escrito iniciará con un primer comentario descriptivo referente a qué se entiende por conflicto de intereses en el derecho societario colombiano, para lo cual se explicará esta institución jurídica a partir de su tratamiento legislativo y reglamentario; en segundo término, de cara al proceso de modernización del derecho societario colombiano, se describirán algunas de las tendencias contemporáneas en materia de tratamiento del conflicto de intereses y, finalmente, se concretarán unos comentarios finales que permitan entender las vicisitudes del régimen vigente y ver hacia dónde debe de enfocarse su análisis.

\section{Aproximación al régimen legal del conflicto de intereses}

Tras dos décadas de vigencia, el estatuto de administradores de sociedades comerciales se alejó de las expectativas iniciales ante su escasa utilización y desarrollo, lo que demuestra que el sistema no funciona adecuadamente, lo cual obedece a una especie de inmovilidad legislativa que conlleva a la petrificación del derecho. En esta sección se realizará una revisión del actual régimen, con el propósito de contextualizar la aludida problemática.

4 A manera de ejemplo, en la lesión enorme en compraventa de bienes inmuebles (artículos 1946 a 1954 del Código Civil), el precio será justo o injusto en cada caso concreto, más no cabe afirmar que existen varios precios justos. 


\subsection{Ley 222 de 1995 [t2]}

El Decreto 410 de 1971, por el cual se expide el Código de Comercio, en términos generales permaneció inalterado durante varios lustros. Con el transcurrir de los años, la realidad, particularmente la económica, puso en evidencia la necesidad de modificaciones sustanciales a la legislación comercial, para convertirla en una adecuada infraestructura jurídica que respondiera eficientemente a la liberalización del comercio y a la modernización de las instituciones económicas ${ }^{5}$.

Así las cosas, fue expedida la Ley 222 de 1995, por la cual se modifica el Libro II del Código de Comercio, se expide un nuevo régimen de procesos concursales y se dictan otras disposiciones, cuyas normas introdujeron modificaciones a las regulaciones comerciales en materia de derecho societario y derecho concursal ${ }^{6}$.

Para efectos del presente documento, interesan las modificaciones al régimen de administradores ${ }^{7}$. En resumen, si bien no se definió qué debe entenderse por administrador, se enumeraron las personas que tienen tal calidad $^{8}$, imponiéndoseles una serie de principios genéricos de conducta,

5 Los planes de desarrollo como expresiones de la política económica del país, a partir de 1970 se empezaron a orientar hacia el mercado. De 1990 en adelante, "en lo económico, se rompió en forma tajante y definitiva con el modelo de desarrollo cepalino basado en la industrialización con sustitución de importaciones y se entró de lleno en una estrategia de apertura de la economía al comercio exterior, proclive a la libre competencia y de toma de decisiones por el mercado" (Blanco, 2013, p. 181).

6 Un análisis de la Ley 222 de 1995, exclusivamente dedicado al tema de las sociedades comerciales, puede verse en Gaviria (2002, p. 239). En cuanto al régimen concursal colombiano, estamos en presencia de una de esas regulaciones del Decreto 410 de 1971, cuyo proceso de consolidación obedece a distintos momentos políticos y económicos, lo cual se evidencia a través de las sustanciales modificaciones legislativas surtidas a lo largo de los últimos veinte años. En palabras de Vélez (2011), "esto no ha sido resultado de improvisaciones, accidentes o actos iluminados. Es, más bien, el producto de décadas de evolución, peldaños puestos en cada época, en cada coyuntura y en gobierno y legislatura, todos conducentes a un marco legal que, como ya dijimos, poco o nada tiene que envidiarle a los regímenes más sofisticados" (p. 5), donde el paradigma económico imperante juega un papel definitivo. Para estudiar el régimen concursal colombiano, tanto empresarial como de personas naturales no comerciantes, ver a Isaza E Londoño (2011.), Pereira (2015) y Rodríguez (2015).

7 Hasta la reforma introducida por la Ley 222 de 1995, en lo que corresponde al régimen de responsabilidad de administradores, sólo existía el artículo 200 del Código de Comercio, para cuyo análisis en su versión previa a la modificación introducida por el artículo 24 de la Ley 222 de 1995, puede verse a Pinzón (1982.

8 En Colombia, cuando se hace referencia a los administradores, se incluyen todos aquellos que están encargados de realizar gestiones sociales en desarrollo del objeto social, es decir, 
pues éstos deben "obrar con buena $\mathrm{fe}^{9}$, con lealtad ${ }^{10}$ y con la diligencia de un buen hombre de negocios ${ }^{11}$ " y la exigencia de actuar en interés de la sociedad ${ }^{12}$ y teniendo en cuenta siempre los intereses de los socios o accionistas. Se precisaron sus responsabilidades y las acciones legales para obtener la indemnización de perjuicios que por dolo o culpa ocasionen a la sociedad, a los socios o accionistas y a los terceros ${ }^{13} \mathrm{y}$, si el administrador es persona jurídica, la responsabilidad recae en ésta y sobre quien funja como su representante legal. También se impuso la rendición de cuentas de los administradores cuando se retiren del cargo o cuando la ley o los estatutos la exijan. Conforme a lo señalado anteriormente, como complemento de los principios generales de conducta reseñados, la reforma incluyó un listado de deberes fiduciarios, cuya inobservancia compromete la responsabilidad de los administradores. En cuanto a los

el representante legal, los miembros de Junta Directiva y las demás personas que las normas particulares señalen. La enumeración restrictiva de quienes tienen la condición de administradores de sociedades comerciales contenida en el artículo 22. ${ }^{\circ}$ de la Ley 222 de 1995, debe entenderse adicionada por el parágrafo del artículo 27 de la Ley 1258 de 2008 que introduce el concepto de administrador de hecho o de facto para la sociedad por acciones simplificada.

9 Corresponde a un postulado constitucional integrador del ordenamiento jurídico y de las relaciones entre particulares y entre éstos y el Estado, que opera como un parámetro general de conducta que permite valorar el comportamiento de las personas, pues incorpora el valor de la confianza en las relaciones sociales. Es un principio reconocido en los artículos 83 de la Constitución Política, 1603 del Código Civil y 871 del Código de Comercio, recogido a su vez en el artículo 23 de la Ley 222 de 1995.

10 Desde el punto de visto del derecho societario, el deber de lealtad en su acepción más general, hace referencia a la fidelidad que deben los administradores en virtud de la confianza que los asociados depositaron en ellos.

11 El cambio de patrón de conducta que deben observar los administradores, es decir, el de un buen hombre de negocios y no el de un buen padre de familia, implica una ampliación sustancial del régimen de responsabilidad de los administradores. Al respecto, la Corte Constitucional, Sala Plena, ha manifestado lo siguiente: “Cabe recordar, que la Ley 222 de 1995, impuso a los administradores un grado de diligencia y prudencia superiores a la mediana que hasta entonces tenían, la de un buen padre de familia, pues ahora deberán actuar con la diligencia propia de un buen hombre de negocios, es decir, con la que pondría un comerciante normal en sus propios asuntos, lo que supone una mayor exigencia en la administración de los asuntos propios de la sociedad" (Sentencia C-123 del 22 de febrero de 2006, expediente D-5936). En sentido similar, ver Corte Constitucional, Sala Octava de Revisión, sentencia T-450 del 26 de mayo de 2011, expediente T-2919871.

12 En su acepción más extendida, el interés social corresponde a la suma de los intereses de los asociados. Sobre este concepto societario ver Morgestein (2011) y Sabogal (2011).

13 En adición a la acción social e individuales que sean del caso, Arrubla (2012) señala que "las acciones de grupo consagradas en la Ley 472 de 1998 son perfectamente posibles para buscar judicialmente la responsabilidad de los administradores" (p. 496). Un detallado análisis sobre la responsabilidad civil de los órganos de dirección y administración de sociedades comerciales puede verse en Santos (2012). 
deberes específicos que han de cumplir los administradores en ejercicio de su gestión, el numeral 7 del artículo 23 de la Ley 222 de 1995 dispone lo siguiente:

Abstenerse de participar por sí o por interpuesta persona en interés personal o de terceros, en actividades que impliquen competencia con la sociedad o en actos respecto de los cuales exista conflicto de intereses, salvo autorización expresa de la junta de socios o asamblea general de accionistas.

En estos casos, el administrador suministrará al órgano social correspondiente toda la información que sea relevante para la toma de la decisión. De la respectiva determinación deberá excluirse el voto del administrador, si fuere socio. En todo caso, la autorización de la junta de socios o asamblea general de accionistas sólo podrá otorgarse cuando el acto no perjudique los intereses de la sociedad.

La disposición legal transcrita, concretamente su primera parte, contiene dos deberes plenamente diferenciados: uno, referente a la prohibición a los administradores de participar en actos que impliquen competencia con la sociedad y otro, relativo a los eventos de conflicto de intereses del administrador frente a la sociedad. Al respecto, Uribe (2013) opina lo siguiente:

Como premisa que aplica para ambos fenómenos, que por cierto es importante aclarar no son idénticos, la ley es explícita e inequívoca al indicar que, en uno y en otro caso, el acto de competencia o constitutivo del conflicto de interés puede verificarse directamente por la acción personal del administrador o indirectamente a través de interpuesta persona. Adicionalmente la ley precisa que no es necesario que el interés de la empresa social sea específicamente el interés personal del administrador, sino que también puede tratarse del interés de un tercero que se encuentre de alguna forma relacionado con el administrador (p. 108).

Teniendo en cuenta lo señalado anteriormente, en lo que respecta exclusivamente al derecho societario ${ }^{14}$ no hay una definición legal de

14 A nivel normativo, en forma excepcional, el Decreto 2555 de 2010, por el cual se recogen y reexpiden las normas en materia del sector financiero, asegurador y del mercado de 
conflicto de intereses que permita determinar cuándo se produce un conflicto de esta naturaleza, indeterminación que se traduce en un amplio campo al servicio de la subjetividad del intérprete.

En Colombia, la Superintendencia de Sociedades, a través de las Circulares Externas 20 del 4 de noviembre de 1997, 100-006 del 25 de marzo 2008 y 100-000003 del 22 de julio de $2015^{15}$, esta última conocida como Circular Básica Jurídica, modificada y adicionada por la Circular Externa 100-000005 del 4 de septiembre de 2015'6, desde una perspectiva general, ha manifestado que "existe conflicto de interés cuando no es posible la satisfacción simultánea de dos intereses, a saber: el radicado en cabeza del administrador y el de la sociedad, bien porque el interés sea del primero o de un tercero" (p. 48) ${ }^{17}$.

Desde la doctrina, los teóricos de la materia han optado por diferentes posiciones. Algunos, al explicar este tópico, comparten y reproducen la definición ofrecida por la Superintendencia de Sociedades, tal como

valores y se dictan otras disposiciones, define en el literal b) del artículo 2.11.4.2.1 el conflicto de interés en los siguientes términos: "Se entiende por conflicto de interés la situación en virtud de la cual una persona en razón de su actividad se enfrenta a distintas alternativas de conducta con relación a intereses incompatibles, ninguno de los cuales puede privilegiar en atención a sus obligaciones legales o contractuales". A renglón seguido, la referida disposición, a título ilustrativo, enumera algunos de los intereses incompatibles que pueden originar una situación de "conflicto de intereses" desde el punto de vista de utilidades contrapuestas. En sentido análogo, ver el artículo 7.6.1.1.2 del referido decreto. Sobre el conflicto de interés en la regulación financiera y del mercado de valores, así como su problemática, ver Buitrago (2013), Córdoba (2014) y Martínez (2004).

15 Sobre la naturaleza jurídica de este tipo de actos administrativos, el Consejo de Estado, Sala de lo Contencioso Administrativo, Sección Segunda, Subsección B, tiene por dicho lo siguiente: "Ha precisado esta Corporación que las instrucciones o circulares administrativas son susceptibles de ser demandadas ante la Jurisdicción Contenciosa si contienen una decisión de la Administración capaz de producir efectos jurídicos frente a los administrados, esto es, si son actos administrativos, pues si se limitan a reproducir el contenido de otras normas o las decisiones de otras instancias o a brindar orientaciones e instrucciones a sus destinatarios sin que contengan decisiones, no serán susceptibles de control judicial. Igualmente se ha sostenido que si las circulares o las cartas de instrucción, tienen por objeto dar a conocer el pensamiento o concepto del superior jerárquico a sus subalternos, en relación con determinadas materias, o impartir instrucciones a los empleados de las distintas dependencias sobre la mejor manera de cumplir las disposiciones normativas, sin que se contengan decisiones, se está en presencia de simples actos de servicio" (Sentencia del 17 de mayo de 2012, expediente 11001-03-25-000-2008-00116-00 (2556-08). En sentido semejante, ver sentencia de la mentada corporación del 20 de marzo de 2013, expediente 08001-23-31-000-2010-00135-01 (1575-12)).

16 De conformidad con los cambios introducidos se ajustó la numeración y los índices, asî como el número de páginas de la Circular Básica Jurídica.

17 En sede administrativa, también pueden verse los conceptos jurídicos contenidos en los Oficios 220-140389 del 27 de noviembre de 2012 y 220-187377 del 10 de noviembre de 2014, entre otros. 
ocurre con Barrero (2011) ${ }^{18}$, Peña (2014) ${ }^{19}$ y Medina $(2015)^{20}$. Otros critican el concepto de conflicto de intereses de la Superintendencia porque no necesariamente las operaciones viciadas por un conflicto de intereses son contrarias al interés social. En este sentido, Córdoba (2014) señala:

En cuanto a la posición de la entidad de control estatal, la citada definición tiene un error sustantivo cuando afirma que es imposible la satisfacción simultánea de los intereses en conflicto, pues dicha opinión elimina, de plano, cualquier posibilidad de que el máximo órgano social otorgue la autorización al administrador, en pleno cumplimiento de la ley y sin perjuicio del interés social, de intervenir en operaciones respecto de las cuales se encuentre en conflicto de intereses.

En otras palabras, pueden existir situaciones de intereses en conflicto con la posibilidad de satisfacerse simultáneamente y eventos en los cuales es imposible dicha solución precisamente porque se perjudicaría el interés social. Un ejemplo del primer caso puede ser los contratos del administrador con la persona jurídica sociedad anónima, como en un arrendamiento de local comercial en el cual funciona un establecimiento de comercio de la compañía, incluso en mejores condiciones que las de mercado y con garantías superiores a las ofrecidas en nuestra legislación mercantil (p. 617).

Antes de pasar a otros autores, Córdoba (2014) complementa lo dicho, sosteniendo que, "para que haya conflicto es necesario que los intereses sean concomitantes, simultáneos en tiempo y en modo, y contrarios pero no necesariamente imposibles de satisfacer al mismo tiempo" (p. 617).

Otros doctrinantes, en la búsqueda de la determinación del conflicto de intereses, han intentado conceptualizarlo, formulando sus propias definiciones. En este orden de ideas, Rengifo (2012) expresa lo siguiente:

18 Transcribe la definición que de conflicto de interés trae la Circular Externa 20 del 4 de noviembre de 1997, derogada por la Circular Externa 100-006 del 25 de marzo 2008, en la cual se repite textualmente el mentado concepto.

19 Transcribe la definición que de conflicto de interés trae la Circular Externa 100-006 del 25 de marzo 2008, derogada por la Circular Externa 100-000003 del 22 de julio de 2015, modificada y adicionada por la Circular Externa 100-000005 del 4 de septiembre de 2015, la cual "recopila las principales instrucciones generales que en materia legal ha emitido la Superintendencia de Sociedades y que hasta la fecha han estado vigentes" (p. 1), incluido el régimen de administradores.

20 Ibídem. 
El conflicto de interés es una situación en la cual se encuentra una persona que está involucrada en varios intereses, uno de los cuales puede incidir desfavorablemente la ejecución del otro. Al representante legal se le ha encargado actuar como órgano volitivo de la sociedad; por lo tanto, él tiene conflictos de interés cuando quiera realizar un acto o negocio jurídico en su propio nombre (o en el de un tercero) y en el de la sociedad. Desde la perspectiva del conflicto de interés, él no puede atender con imparcialidad al mismo tiempo los dos intereses contrapuestos (p. 187).

Por su parte, Uribe (2013) señala lo que sigue:

[...] habría conflicto de interés cuando en un mismo momento en cabeza de una misma persona se conjuga la necesidad de escoger entre uno de dos intereses que son contrapuestos entre sí, en este caso el interés de la sociedad administrada de una parte y por la otra, el interés propio del administrador o de un tercero con el que se encuentre relacionado. La necesidad de escogencia, implicará que necesariamente se favorecerá un interés y por consiguiente se afectará y lesionará el otro dado que es imposible su satisfacción simultánea (p. 117).

Martínez (2014) reproduce la definición expuesta por la Superintendencia de Sociedades en 1997 y, a renglón seguido, manifiesta:

Así, en su sentido prístino el conflicto de interés se configura, en nuestro parecer, cuando una persona se encuentra en una disyuntiva de naturaleza jurídica y moral sobre los efectos, beneficios o perjuicios, de las conductas alternativas que puede realizar frente a una determinada situación, teniendo en cuenta la posibilidad de que se involucren sus propios intereses, los de la entidad que administra y los de sus vinculadas y los de su clientela (p. 193).

Gil (2015), al referir la noción de conflicto de intereses en materia societaria, señala que "como su nombre lo indica, corresponde a una contraposición entre el interés de la sociedad administrada, y el interés directo o por interpuesta persona, de un administrador" (p. 309). Agrega este autor, concretando aún más su concepto, que "a título general, bien puede afirmarse que habrá conflictos de intereses siempre que el 
administrador pretenda celebrar, ordenar, o ejecutar un acto o contrato con la sociedad, teniendo un interés directo o por interpuesta persona, en el mismo acto o contrato" (p. 310).

Si bien la Superintendencia de Sociedades y la doctrina nacional han sentado parámetros alrededor de la idea del conflicto de intereses, en la práctica la ausencia de una definición legal se ha utilizado para evadir el régimen de responsabilidad de administradores, así como para interpretaciones confusas en punto de la existencia del aludido conflicto en ciertas hipótesis como, por ejemplo, en operaciones con sociedades controladas por familiares del administrador o negocios que favorezcan al asociado o asociados controlantes, lo que se traduce, entre otras cosas, en desviación de beneficios privados inherentes al control ${ }^{21} \mathrm{y}$ situaciones especialmente perjudiciales para los socios o accionistas minoritarios.

Lo anterior corresponde a una proclive tendencia de nuestro de legislador de admitir el uso de tipos abiertos y de "conceptos jurídicos indeterminados", a la vez que le atribuye al juzgador una mayor amplitud para adelantar el proceso de adecuación típica de las conductas reprochables, lo que implica una pesada carga para los operadores judiciales, quienes en cada caso deberán realizar un riguroso escrutinio tendiente a verificar si han mediado los supuestos de hecho que podrían subsumirse en un "conflicto de intereses".

De cierta forma, esta es una técnica útil para el legislador, pero no necesariamente es la más idónea, más aún con respecto a la temática objeto de estudio. El legislador nacional no se preocupó por definir y delimitar el concepto de conflicto de intereses, así como tampoco lo hizo con el concepto de "buen hombre de negocios" (entre otras aristas

21 Estos beneficios se entienden como las rentas que los administradores o asociados controlantes pueden extraer de la sociedad, generalmente a expensas o en perjuicio de los minoritarios. En palabras de Jurfest, Paredes \& Riutort (2015), estos beneficios privados del control "se refieren a desviar valor desde los accionistas minoritarios hacia los controladores, por ejemplo, mediante el self-dealing (transacciones con personas o empresas relacionadas), el desvío de oportunidades corporativas a otros negocios del controlador, aunque también existen otro tipo de beneficios no pecuniarios que no dañan a los accionistas minoritarios, como los provenientes de sinergias o los beneficios psíquicos y el estatus social que resultan del control" (p. 848). Entre otras tácticas que ejemplifican como los administradores desvían recursos de la sociedad a su favor, se tienen el uso de información estratégica de la sociedad, coinversiones con sociedades de los administradores, ventas de activos de negocios interconectados, etc. Este tipo de transacciones se adelantan a través de estrategias complejas, las cuales se tratan de legitimar al amparo del "interés de la sociedad". 
del régimen de administradores) lo que causa un elevado grado de vaguedad, por lo que su orientación y aplicación práctica en un momento dado corresponde precisar a la jurisprudencia, lo cual merece algunas reservas - y críticas - por su conocida abstracción y generalidad, así como por el riesgo ante la interpretación que antojadizamente pueda darle un operador judicial al conflicto de intereses.

Desde la perspectiva de los administradores, conforme al aforismo ignoratia juris non excusat (la ignorancia no exime del cumplimiento de la ley) que encuentra consagración legal en el artículo 9 del Código Civil ${ }^{22}$, el vacío legal en ciernes genera serias dudas alrededor de qué situaciones pueden considerarse conflictivas, pues no todos ellos estarán en capacidad de realizar el análisis que permite determinar si su actuar se enmarca en un conflicto de intereses. A esta dificultad práctica debe agregársele las duras sanciones, incluida la posible inhabilidad para ejercer el comercio, que implica la violación de la disposición legal objeto de estudio, lo que indefectiblemente desestimula la asunción de riesgos que es propia de la gestión de los administradores de sociedades comerciales.

Explicitado lo anterior, en relación con la segunda parte del numeral 7 del artículo 23 de la Ley 222 de 1995, ante la presencia de operaciones conflictivas, pueden separarse las nocivas de las eficientes. En relación con lo dicho, Reyes (2016) enseña lo siguiente:

La norma citada parte de una prohibición de carácter general para ejecutar unos y otros actos, pero dispone que, sin embargo, podrán realizarse tales actividades, siempre que se cumpla un procedimiento previsto en el mismo precepto. Quiere esto decir que las operaciones conflictivas o de competencia con la sociedad no son necesariamente perjudiciales para ella. En efecto, bajo ciertas circunstancias, determinado negocio puede resultar útil para ambas partes (p. 712).

En sentido semejante se pronuncia Gil (2015), quien expone lo que sigue:

22 Esta disposición fue declarada exequible por la Corte Constitucional, Sala Plena, mediante sentencia C-651 del 3 de diciembre de 1997, expediente D-1698. 
Desde ahora debe quedar claro que la sola existencia de un conflicto de interés no significa, necesariamente, que la operación proyectada tenga la virtud de resultar perjudicial para la sociedad administrada, relación jurídica que bien puede ser beneficiosa para la empresa. Esta es la razón por la cual la ley no proscribe totalmente los actos o contratos conflictuales, sino que los sujeta a la previa autorización del máximo órgano social, y los condiciona al hecho de que no sean perjudiciales a la sociedad [...] (p. 311) 23 .

Por su parte, Córdoba (2014), en sintonía con la línea doctrinal expuesta en precedencia, señala:

[...] el mero conflicto no constituye por sí solo una conducta que contraría la prestación de lealtad a cargo de los administradores de la sociedad anónima, más aún cuando el ordenamiento jurídico en la norma acabada de citar permite una solución del conflicto que puede, sin perjudicar el interés social, lograr una composición de intereses [...] no se puede partir del supuesto consistente en que el conflicto de intereses per se constituye una afectación al interés social, pues ello equivaldría a predicar la responsabilidad de los directores por la sola existencia de un conflicto de intereses y por ende la legitimación jurídica de la sociedad para iniciar la correspondiente acción social de responsabilidad. La incompatibilidad de los intereses no significa automáticamente sacrificio alguno de ellos, sin olvidar obviamente que en caso de imposible composición prevalece el interés social (pp. 617-618).

La dificultad práctica consiste en que el sistema de autorización en comento no tiene en cuenta los problemas de agencia o mandato entre mayoritarios y minoritarios. En sistemas de capital concentrado como el nuestro, típico en Latinoamérica, quien más aporte de capital realiza es quien accede al control de la compañía, razón por la cual Reyes (2013a) señala que "como resultado de la estructura de capital en las sociedades latinoamericanas, el aspecto central en los regímenes societarios de esta región es la posible divergencia de intereses entre accionistas mayoritarios y minoritarios" (p. 15).

23 Las itálicas son propias. 
Conforme a lo anterior, si bien se excluye el voto del socio o accionista que sea administrador, la decisión puede tomarse por mayoría, por lo que con el voto del socio o accionista controlante se pueden legitimar operaciones que lo beneficien, pero que eventualmente perjudiquen a la sociedad. Algo similar ocurre con la acción social de responsabilidad, descartándola respecto de operaciones que beneficien al mayoritario ${ }^{24}$.

Otra dificultad tiene que ver con la práctica recurrente y consistente en que el administrador inmerso en un conflicto de intereses se abstiene de votar, para que sean sus pares quienes decidan en relación con la situación conflictual, sustrayéndose así del sistema de autorización obligatorio por parte de la junta de socios o asamblea general de accionistas. En el derecho societario contemporáneo se ha acuñado el término back scratching (rascarse la espalda), para describir esta práctica.

\subsection{Decreto 1925 de 2009}

En atención a las anteriores dificultades y ante el escaso uso del régimen de conflicto de intereses el Ministerio de Industria, Comercio y Turismo expidió el Decreto 1925 de 2009, por medio del cual se reglamenta parcialmente el artículo 23 de la Ley 222 de 1995, y demás normas concordantes, en lo relativo a conflictos de interés y competencia con la sociedad por parte de los administradores de la sociedad"25. Sobre esta reglamentación, Reyes (2013b) ha expresado lo siguiente:

24 En relación con el procedimiento establecido en el artículo 25 de la Ley 222 de 1995 , la Delegatura para Procedimientos Mercantiles de la Superintendencia de Sociedades en el caso Jovalco S.A.S. v. Construcciones Orbi S.A. (Sentencia No. 800-54 del 14 de mayo de 2015) señaló lo siguiente: "En verdad, la decisión de presentar la acción respectiva dependerá del voto del accionista controlante, vale decir, la persona que tiene a su cargo, en forma directa o indirecta, la administración de la sociedad. Es entonces poco probable que el controlante decida tramitar un proceso judicial en contra de sí mismo o, incluso, en contra de las personas que ha designado para ocupar cargos en la administración. La probabilidad de que se inicie una acción social de responsabilidad es aún menor si los perjuicios que justifican la demanda provienen de una operación que favoreció en forma exclusiva al asociado controlante".

25 Contrario a lo ocurrido con el control de los actos que comportan conflicto de intereses, el régimen de grupos empresariales y control de sociedades, también regulado en la Ley 222 de 1995, sí ha tenido un desarrollo importante a través de diferentes leyes y decretos que, directa o indirectamente, tienen que ver con matrices, subordinadas, grupos y vinculados. A manera de ejemplo, entre otras, tenemos las siguientes disposiciones: Ley 488 de 1998, Ley 550 de 1999 , Decreto 2250 de 2000, Ley 788 de 2002, Ley 863 de 2003, Ley 1116 de 2006, Decreto 4350 
En esta relevante disposición se reiteran las pautas previstas en la Ley 222, se desarrolla el procedimiento que debe seguirse en caso de conflictos de interés o competencia con la sociedad, y se regulan las sanciones que han de imponérseles a los administradores y accionistas que transgredan la referida regulación. Así mismo, el precepto estatuye la sanción a que se sujetan los negocios jurídicos realizados en contravención al procedimiento indicado (p. 163).

No obstante, el Decreto 1925 de 2009 ha sido criticado en varios puntos. Frente a la responsabilidad del administrador, la mentada reglamentación es del siguiente estilo:

Artículo 1. El administrador que incurra por sí o por interpuesta persona, en interés personal o de terceros, en conductas que impliquen conflicto de interés o competencia con la sociedad en violación de la ley y sin la debida autorización de la Asamblea General de Accionistas o Junta de Socios, responderá solidaria e ilimitadamente de los perjuicios que por dolo o culpa ocasione a los asociados, a la sociedad o a terceros perjudicados, con el propósito de lograr, de conformidad con la ley, la reparación integral.

En relación con la disposición antes transcrita, Córdoba (2014) reprocha lo siguiente:

[...] de manera poco lógica consagra la responsabilidad del administrador por el solo conflicto y, para mayor equivocación, señala que la única solución es que el máximo órgano haya conocido previamente de la situación en conflicto, como si el administrador pudiera conocer y evitar siempre un supuesto de hecho de esta naturaleza.

La respuesta del ordenamiento jurídico debe dirigirse, si se persiste en dicha óptica punitiva, a castigar al administrador que se aprovecha, a expensas del interés social, de una situación de conflicto de intereses y no por el simple hecho de estar en la citada circunstancia (p. 615).

También son criticables el sistema de responsabilidad de accionistas y la sanción de nulidad absoluta del acto o contrato ejecutado en con-

de 2006, Decreto 4334 de 2008, Decreto 1746 de 2011. Sobre esta temática ver a Gaitán (2011) y Galgano, Roitman, León \& López (2012). 
travención del régimen en mención que introduce el Decreto 1925 de 2009. Dicha reglamentación establece lo siguiente:

Artículo 4. Los socios que hayan autorizado expresamente la realización de un acto respecto del cual exista conflicto de interés o competencia con la sociedad, que perjudique los intereses de la sociedad, serán responsables solidaria e ilimitadamente por los perjuicios que ocasionen a ésta, a los socios y a terceros, salvo que dicha autorización se haya obtenido de manera engañosa. Lo anterior, sin perjuicio de la declaratoria de nulidad que pudiese resultar de los actos amparados en tales decisiones por violación de la ley.

Artículo 5. El proceso judicial para obtener la declaratoria de nulidad absoluta de los actos ejecutados en contra de los deberes de los administradores consagrados en el numeral 7 del artículo 23 de la Ley 222 de 1995, se adelantará mediante el proceso legalmente establecido, de conformidad con el artículo 233 de la Ley 222 de 1995; sin perjuicio de otros mecanismos de solución de conflictos establecidos en los estatutos. Salvo los derechos de terceros que hayan obrado de buena fe, declarada la nulidad, se restituirán las cosas a su estado anterior, lo que podría incluir, entre otros, el reintegro de las ganancias obtenidas con la realización de la conducta sancionada, sin perjuicio de las acciones de impugnación de las decisiones, de conformidad con lo dispuesto en el artículo 191 y siguientes del Código de Comercio.

Mediante este mismo trámite, el administrador que obre contrariando lo dispuesto en el artículo 23 de la Ley 222 de 1995, será condenado a indemnizar a quien hubiese causado perjuicios. El juez competente, según lo establecido en la ley, podrá sancionar a los administradores con multas y/o con la inhabilidad para ejercer el comercio, sin perjuicio de la responsabilidad penal que dicha conducta pudiese generar.

Parágrafo. En el caso de que la sociedad hubiese pactado cláusula compromisoria o compromiso, se estará a las normas respectivas. En el caso de la Sociedad por Acciones Simplificada se aplicará el artículo 44 de la Ley 1258 de 2008.

En atención al mandato del numeral 11 del artículo 189 de la Constitución Política, le corresponde al Presidente de la República "ejercer la potestad reglamentaria mediante la expedición de decretos, resoluciones y órdenes para la cumplida ejecución de la ley", consagración que le 
permite desarrollar su contenido con la finalidad de conseguir que la ley que reglamenta sea entendible y fácilmente aplicable, de donde se colige que el decreto reglamentario que se expide en virtud de tales facultades, no le permite al Gobierno Nacional exceder las competencias conferidas, como tampoco fijar elementos o requisitos diferentes a la norma, lo cual no ocurrió en el presente caso, pues el citado decreto excedió lo establecido por la disposición reglamentada en la medida que las sanciones anotadas previamente no están consagradas en el numeral 7 del artículo 23 de la Ley 222 de 1995, lo que implica una extralimitación en las atribuciones legales y constituciones conferidas.

Debe precisarse que, con el objetivo de racionalización y simplificación normativa, el Ministerio de Industria, Comercio y Turismo expidió el Decreto 1074 de 2015, por medio del cual se expide el Decreto Único Reglamentario del Sector Comercio, Industria y Turismo, el cual compila las normas reglamentarias preexistentes del aludido sector, derogándose las disposiciones que traten las mismas temáticas, salvo los asuntos referidos en su artículo 3.3.1.

Entre los temas compilados se encuentra el conflicto de intereses con la sociedad por parte de los administradores de las mismas reglamentado en su momento por el Decreto 1925 de 2009, el cual se entiende derogado $^{26}$. Las disposiciones reglamentarias recopiladas que se han comentado y que interesan a este escrito, fueron reproducidas en los artículos 2.2.2.3.1. a 2.2.2.3.5.

\section{Tendencias contemporáneas en materia de "conflicto de intereses"}

Durante los últimos años, el derecho societario colombiano ha sido objeto de un proceso de modernización a través de distintas disposiciones,

26 Frente a la derogatoria que utiliza el Decreto 1074 de 2015 respecto de las disposiciones compiladas, se aplicó la denominada derogatoria integral o sistemática contenida en el artículo 3 de la Ley 153 de 1887, por lo que perdieron vigencia todas las normas que versen sobre las mismas materias anteriores al decreto, lo que implica un cambio completo respecto de las referencias normativas a las que estamos acostumbrados cuando nos referimos a reglamentaciones. Este tipo de derogatoria fue aplicado por el artículo 2033 del Decreto 410 de 1971, por el cual se expide el Código de Comercio. 
replanteándose diversos paradigmas existentes en la materia ${ }^{27}$, por lo que es necesario revisar cómo ha sido el tratamiento en materia de conflicto de intereses en otros países, para entender las discusiones actuales que se están dando sobre el tema y que se nutren de las más modernas tendencias del derecho comparado.

\subsection{Estados Unidos}

El derecho societario norteamericano es un referente en los procesos de reformas legislativas a las regulaciones societarias debido a sus desarrollos prácticos. Al respecto, Posada (2008) señala lo siguiente:

[...] la importancia económica de los EE.UU., así como el carácter práctico de sus instituciones legales, ha determinado una influencia global innegable en la mayoría de los campos del Derecho. Incluso la doctrina europea ha reconocido esta situación. Pierre Mousseron, por ejemplo, ha sostenido que la globalización ("mondialisation") del Derecho Societario es la expresión escogida para designar la "americanización" de este campo del Derecho (p. 119).

Por su parte, Navarro (2014) al referirse a esta legislación, manifiesta:

Por lo que respecta a EE.UU., a priori hay que tener en cuenta que muchas tendencias que se vislumbran en el Derecho societario mundial tienen su origen allí. En este sentido, durante las últimas décadas se han producido en este país profundos cambios caracterizados por una creciente desregulación de su Derecho de sociedades, que supone la sustitución de normas imperativas por otras de carácter dispositivo. [...] Bajo estas premisas, no cabe duda de que nos encontramos ante un ordenamiento peculiar que trata de dar cabida a cualquier necesidad práctica y que puede considerarse un exponente en lo que a flexibilización societaria se refiere (p. 65).

Precisado lo anterior, el análisis del conflicto de intereses de los administradores de sociedades en los Estados Unidos de América se enmarca de 2010 .

27 Se destacan, entre otras, las Leyes 222 de 1995, 1014 de 2006, 1258 de 2008 y 1429 
dentro de la aplicación de la doctrina general de los deberes fiduciarios, conforme a los cuales "se considera que existe una relación fiduciaria del administrador con la sociedad, por virtud de la cual esta deposita su confianza en el juicio y consejo de aquel" (Reyes, 2010, p. 343).

Si bien existen variados deberes fiduciarios, en términos generales se ha decantado una tipología básica, enmarcando la conducta de los administradores dentro de las nociones de deber de cuidado (duty of care) y deber de lealtad (duty of loyalty). Por el primero, los administradores deben ser diligentes en relación con el encargo recibido, es decir, en el manejo de los asuntos societarios; por el segundo, los administradores deben actuar atendiendo los intereses de la sociedad. Al respecto, en la Nueva Ley Tipo de Sociedades de Capital (The Revised Model Business Corporation Act), Capítulo 8 - Miembros de Junta Directiva y Representantes Legales (Chapter 8 - Directors and Officers ${ }^{28}$ ), Secciones 8.30 y 8.42 , se señala que éstos deben cumplir sus deberes "con el mismo cuidado con el que actuaría una persona prudente bajo las mismas circunstancias", así como "actuar de la manera que crean razonablemente es en los mejores intereses de la compañía".

En relación con el deber de lealtad, su principal regla consiste en la prohibición al administrador de actuar en transacciones que impliquen conflicto de intereses (selfdealing transactions), cuya aplicación ha pasado por diversas etapas, las cuales son descritas por Bernet (2007) en los siguientes términos:

En un principio se dispuso una regulación rígida, proveniente del Common Law, que prohibía cualquier forma de self-dealing transaction, con independencia de sus resultados económicos, debido a que tales negocios se celebraban en un evidente conflicto de interés que el

28 No existe en el derecho societario estadounidense un término que agrupe tanto a los miembros de Junta Directiva (directors) como a los representantes legales (officers). En relación con la diferencia entre unos y otros, Miguens (2010) señala que, "cuando se habla 'directores' se está haciendo referencia a los miembros del directorio del máximo nivel jerárquico de gobierno y administración societaria. Equivale a 'directors' en el derecho societario norteamericano". Por el contrario, "officers' [...] se refiere a los órganos societarios de administración subordinados a los directores, que en muchos países del derecho continental europeo equivale a 'gerentes' o jefes de área en la administración". Por otra parte, "se habla de 'officials' o 'employees' para designar a los empleados de la sociedad que están jerárquicamente por debajo de los 'officers', aunque pueden estar jerarquizados y tener funciones de mando" (p. 66). 
Derecho no debía amparar, siendo declarados nulos sistemáticamente por los tribunales.

Luego, tal regla se fue atemperando, permitiéndose que pudieran efectuarse tales negocios si eran aprobados por la mayoría de los directores independientes y eran considerados justos para la sociedad.

Con posterioridad, en un tercer estado, la regla se flexibilizó aún más, exigiéndose que la transacción sea únicamente justa, pudiendo ser discutida esa calidad por los tribunales.

Por último, para algunos comentaristas existiría una cuarta etapa en la cual, si el negocio es aprobado por una instancia independiente, los tribunales carecerían de la posibilidad de revisar la equidad de tal transacción al estar amparada por la llamada business judgment rule (p. 114).

La aplicación de la prohibición para el administrador de actuar en conflicto de intereses, también conocida como prohibición de actuar en conflicto entre el deber y el interés (no conflict rule), es fruto de la casuística, por lo que jurisprudencial y doctrinariamente se ha procurado articular las transacciones más recurrentes que violan la mentada regla y, por ende, el deber de lealtad. Reyes (2013c), reseñando la más autorizada doctrina, pone de presente lo siguiente:

Clark afirma que en esta clase de negocios pueden incluirse conductas tales como las que a continuación se enuncian: '1) actos u operaciones realizados entre una sociedad y sus administradores; 2) operaciones entre dos compañías, de manera que un individuo se desempeñe como administrador de una, a pesar de tener intereses económicos en la otra; 3) operaciones entre sociedades matrices y subordinadas en las que quien se desempeñe como administrador de las primeras tenga participaciones de capital en las segundas, y 4) actos u operaciones cumplidos entre sociedades que compartan los mismos administradores' (p. 232).

No obstante, los estándares de revisión de las operaciones en las que medie un conflicto de intereses también están dados por las particulares regulaciones en el contexto de las legislaciones estatales de EE.UU. A manera de ejemplo: el régimen sustantivo de sociedades del Estado de Delaware (Delaware General Corporation Law), uno de los más avanzados, se caracteriza por reglas flexibles sobre la materia. Al respecto, Reyes (2013c) señala: 
A la luz de esta legislación de vanguardia, la regla general consiste en que los negocios jurídicos celebrados entre los administradores y las sociedades en que desarrollan su gestión no adolecen per se de nulidad. De manera excepcional, la referida sanción podría aplicarse en los siguientes supuestos: 1) en aquellos eventos en que los administradores no hubieren revelado toda la información relacionada con la operación que se proponían acometer; 2) en cualquier caso en que los administradores hubieran actuado de mala fe durante la fase precontractual, y 3 ) en hipótesis en que el acto u operación hubiere sido nocivo para la sociedad o pudiere resultarle perjudicial en el futuro ${ }^{29}$. Mediante la implantación de este sistema permisivo, la legislación de Delaware ha tenido el efecto de reducir la injerencia de las cortes en las mencionadas operaciones. Se trata de un significativo beneficio conferido a los administradores, cuya consagración normativa forma parte también de las numerosas facetas que atenúan el rigor de las regulaciones societarias. Esta particular normativa ha contribuido al mantenimiento de la hegemonía del aludido estado dentro del mercado de leyes de sociedades (pp. 232-233).

Las reglas adoptadas en el estado de Delaware se complementan con un sofisticado sistema de fiscalización, el cual es descrito por Mendoza (2015), así:

En las compañías constituidas conforme a las leyes de ese estado, los administradores cuentan con absoluta discreción para celebrar operaciones viciadas por conflictos de interés. Sin embargo, la Corte de Cancillería suele ejercer un cercano escrutinio judicial para establecer si tales operaciones le generaron perjuicios a la sociedad. Tras detectarse un posible conflicto de interés, la Corte de Cancillería puede escoger entre examinar la operación bajo el más estricto criterio de revisión judicial (entire fairness test) o invocar la regla de la discrecionalidad (business judgment rule) para abstenerse de auscultar la decisión correspondiente. La definición del criterio que usará la Corte (entire fairness test o business judgment rule) dependerá de la naturaleza de la operación, las partes que

29 Ver Código del Estado de Delaware (Delaware State Code), Título 8 Sociedades (Title 8 Corporations), Capítulo 1 Ley General de Sociedades (Chapter 1 General Corporation Law), Subcapítulo IV Miembros de Juntas Directivas y Representantes Legales (Subchapter IV Directors and Officers), Sección (Section §) 144 (a). 
participaron en ella y el procedimiento que se siguió para aprobarla. Es usual que la Corte fundamente su decisión en circunstancias tales como la celebración de operaciones con los accionistas controlantes, la ratificación por comités especiales de miembros independientes de la junta directiva y la aprobación impartida por una mayoría de accionistas que no tengan un interés directo en la respectiva operación (pp. 56-57).

\subsection{Alemania}

En el devenir de los procesos de reformas realizadas en las legislaciones societarias europeas, el acontecido en la República Federal de Alemania a partir de 1994 es importante, toda vez que no se reduce exclusivamente a medidas más flexibles. Al respecto, Vásquez (2015) explica lo siguiente:

[...] la relevancia de la reforma de la AktG de 1994, no radicó tanto en el régimen simplificado que introdujo para las sociedades anónimas cerradas, como en constituir el primer paso de un proceso más profundo, pues luego de esta ley se han sucedido varias otras, en el marco de un proceso de revisión del régimen jurídico de la sociedad anónima alemana, que aún no se cierra. Este fenómeno es conocido como 'la permanente reforma del derecho de las sociedades por acciones' (pp. 79-80).

En este contexto, en lo que resulta concerniente a este escrito, el derecho societario alemán es una guía de referencia en relación con las operaciones entre sociedades de un mismo grupo como escenario para el conflicto de intereses. En este sentido, Sabogal (2014) manifiesta:

[...] el derecho alemán ha sido probablemente el ordenamiento jurídico que más ampliamente se ha ocupado de regular la situación de los conflictos de interés de los administradores en las empresas de grupo, lo que se evidencia en una extensa regulación en el libro tercero (titulado "Empresas Vinculadas") de la Ley de Sociedades Anónimas, y en particular los artículos 308 a 312 y 317 a 318 AktG (p. 12).

A partir de lo anterior, el tratamiento del conflicto de intereses de los administradores de sociedades en grupo empresarial en Alemania es explicado por el mismo Sabogal (2014) en los siguientes términos: 
En este país, en aquellos grupos organizados bajo 'contrato de dominación' ${ }^{30}$, la matriz tiene el poder de ordenar a sus subsidiarias adecuarse al interés de grupo. Pero para que ello sea posible en el contrato de dominación debe preverse una 'compensación adecuada a los accionistas externos' y además debe indemnizarse a las subsidiarias por los daños que hubieren sufrido por actuar conforme a las instrucciones de grupo, o de lo contrario, los accionistas minoritarios tendrían acción de responsabilidad contra la controlante. Bajo este escenario, debe precisarse en cualquier caso que los administradores (representante legal y miembros de los consejos de dirección y vigilancia) de la controlante tienen la obligación de impartir las instrucciones siguiendo los deberes generales de diligencia y lealtad, o de lo contrario quedarán obligados a indemnizar los daños producidos [art. 309 y 310 AktG].

Por el contrario, en aquellos grupos de hecho (aquellos que no están organizados bajo un contrato de dominación) la matriz no tiene la facultad de obligar a sus subsidiarias a actuar de forma contraria al interés social. Así pues, si se emite una instrucción de esta naturaleza la controlante, solidariamente con los administradores de ésta, tendrán la obligación de indemnizar a la sociedad dependiente por los daños ocasionados [Art. 317 AktG]. Así mismo, la ley prevé la obligación de indemnizar a los accionistas de la sociedad dependiente por los daños sufridos por ellos como consecuencia del perjuicio causado a la sociedad. Finalmente, la ley prevé una obligación de información al final del ejercicio de las operaciones vinculadas llevadas a cabo entre la controlante y sus controladas, junto con los motivos, las contraprestaciones que se reciben a cambio y la manera de compensación de perjuicios en caso de haberse presentado [art. 312 AktG] (pp. 12-13).

\subsection{España}

En relación con el panorama societario existente en España, Navarro (2014) expresa lo siguiente:

30 Alemania adoptó el modelo contractual para regular los grupos económicos a través los konzern o contratos de dominio. De esta forma, "el convenio se constituye, entonces, en un puerto al que arriba el grupo fáctico y no se trata simplemente de un punto de partida. Esto quiere decir, que el contrato de dominio es la legalización del ejercicio meramente fáctico de la dirección unitaria y no un simple instrumento de obtención del control" (Gaviria, 2005, p. 92). 
En la actualidad, la S.A. en España está concebida para un tipo de sociedad abierta, que por su tamaño financia su capital de riesgo en el mercado y cuyas partes sociales reciben el nombre de acciones. Sus socios en ocasiones cambiantes, no suelen intervenir en la gestión directa de la sociedad. Frente a ella la SRL se concibe para un tipo de sociedad cerrada, que no recurre al ahorro público en el mercado para financiar su capital si no que lo hace exclusivamente a expensas de sus socios, los cuales intervienen de forma directa en la vida de la sociedad (p. 67).

Bajo este panorama, la reforma más significativa al derecho societario español se dio a través del Real Decreto Legislativo 1/2010, del 2 de julio, por el cual se aprobó el texto refundido de la Ley de Sociedades de Capital (LSC), recogiéndose la normativa referente a las sociedades anónimas (Real Decreto Legislativo 1564/1989, del 22 de diciembre), las sociedades de responsabilidad limitada (Ley 2/1995, del 23 de marzo), las sociedades anónimas cotizadas (título X de la Ley 24/1988, del 28 de julio) y las sociedades comanditarias por acciones (sección 4 del título I del libro II del Código de Comercio de 1885).

La LSC ha sido recientemente reformada para la mejora del gobierno corporativo por la Ley 31/2014, del 3 de diciembre, modificándose, entre otras disposiciones, las normas aplicables a los administradores en las sociedades de capital. Al respecto, Sánchez-Calero (2015) señala:

Como señala expresamente su preámbulo, la tipificación más precisa de los deberes de los administradores ha sido uno de los contenidos esenciales de la reforma operada en la LSC por la reiterada Ley 31/2014. La reforma ha significado la reformulación de cada uno de esos deberes clásicos y obligatorios para todo administrador (diligencia, lealtad y secreto) y el establecimiento con respecto al deber de lealtad de soluciones especiales en cuanto a la imperatividad de su régimen legal y con respecto a la acción social basada en su infracción (p. 897).

En atención a los cambios introducidos, el artículo 227 (1) de la LSC atinente al deber de lealtad, dispone que "los administradores deberán desempeñar el cargo con la lealtad de un fiel representante, obrando de buena fe y en el mejor interés de la sociedad", cláusula general 
complementada con una enumeración legal no taxativa de las "obligaciones básicas derivadas del deber de lealtad" (artículo 228 de la LSC).

De la mentada relación de obligaciones, en lo que respecta al conflicto de intereses, es de resaltar el artículo 228 (e) de la LSC, norma según la cual el deber de lealtad obliga al administrador a "adoptar las medidas necesarias para evitar incurrir en situaciones en las que sus intereses, sean por cuenta propia o ajena, puedan entrar en conflicto con el interés social y con sus deberes para con la sociedad". Esta importante disposición es explicada por Díaz (2015), así:

Pues bien, con el artículo 228e de la Ley de Sociedades de Capital nuestro ordenamiento incorpora una suerte de no-conflict rule. La ley no se limita a exigir del administrador que si se llega a encontrar en una situación de conflicto de intereses lo comunique (deber de información ${ }^{31}$ y se abstenga de participar en cualquier decisión relativa a ella, sino que, como medida preventiva, le impone específicamente el deber de eludir tales situaciones. No se trata sólo de impedir que el administrador anteponga sus intereses a los de la compañía en caso de que el conflicto se actualice (básicamente prohibiéndole intervenir en la gestión social en lo que se refiere a esos asuntos), sino de evitar, incluso, que surja el mismo riesgo de que ello suceda (siguiendo así la máxima de san Ignacio: "Quien evita la tentación evita el pecado». En todo caso, y naturalmente, cuando el interés del administrador sea indirecto (por materializarse a través del interés de un tercero), el deber de evitar el conflicto deberá modularse y concretarse en atención a la capacidad de control que aquél tenga sobre ese tercero (p. 28).

Como complemento de lo anterior, el artículo 229 (1) de la LSC trae una enumeración no exhaustiva de prohibiciones que derivan del deber de evitar las situaciones en las que los intereses de la sociedad y los del administrador - o de otras personas en cuyo interés actúe- entren en conflicto:

1) Realizar transacciones con la sociedad, excepto que se trate de operaciones ordinarias, hechas en condiciones estándar para los clientes y de escasa relevancia, entendiendo por tales aquéllas cuya información

31 Artículo 229 (3) de la LSC. 
no sea necesaria para expresar la imagen fiel del patrimonio, de la situación financiera y de los resultados de la entidad.

2) Utilizar el nombre de la sociedad o invocar su condición de administrador para influir indebidamente en la realización de operaciones privadas.

3) Hacer uso de los activos sociales, incluida la información confidencial de la compañía, con fines privados.

4) Aprovecharse de las oportunidades de negocio de la sociedad.

5) Obtener ventajas o remuneraciones de terceros distintos de la sociedad y su grupo asociadas al desempeño de su cargo, salvo que se trate de atenciones de mera cortesía.

6) Desarrollar actividades por cuenta propia o cuenta ajena que entrañen una competencia efectiva, sea actual o potencial, con la sociedad o que, de cualquier otro modo, le sitúen en un conflicto permanente con los intereses de la sociedad.

Por su parte, el artículo 229 (2) de la LSC señala que "las previsiones anteriores serán de aplicación también en el caso de que el beneficiario de los actos o de las actividades prohibidas sea una persona vinculada al administrador", evitándose de esta forma el traslado de las actividades prohibidas a terceros en las condiciones anotadas, por lo que las relaciones de parentesco, la concurrencia en otros negocios, la integración en un grupo, entre otros, son criterios analíticos para identificar un conflicto de intereses en operaciones con partes relacionadas.

En los términos del artículo 230 (1) de la LSC, las disposiciones en relación con el deber de lealtad y la responsabilidad por sus infracciones son de orden público, razón por la cual las cláusulas estatutarias que pretendieren apartarse del régimen legal en comento, limitándolo o atemperándolo o que resultaren contrarias al mismo, no serían válidas.

A renglón seguido, elartículo 230 ( 2 y 3) de la LSC establece un sistema de autorización denominado "dispensa" en relación con las prohibiciones reseñadas en el artículo 229, lo que evidencia la relatividad de las mismas. Sobre la naturaleza de este régimen de excepción, SánchezCalero (2015) manifiesta:

La dispensa será siempre excepcional por ser especial, esto es, por referirse a casos singulares. Ha de descartarse la posibilidad de dispensas 
genéricas a favor de un determinado administrador, o proyectadas sobre operaciones, negocios o cualesquiera otros actos pertenecientes a una determinada categoría. El objeto de la dispensa es la observancia de cualquiera de las concretas prohibiciones contenidas en el artículo 229.1 LSC. La concesión de la dispensa supone autorizar expresamente que el administrador pueda realizar una operación que está prohibida con carácter general. Beneficiario directo de la dispensa puede ser un administrador, pero puede serlo también una persona vinculada con él, afectada por la prohibición contemplada en artículo 229.2 LSC. La dispensa se puede referir a cualquiera de las hipótesis de abstención que vimos que establece el artículo 229.1 LSC, si bien su objeto hace que varíe la competencia para concederla (p. 912).

Ante la eventual infracción al deber de lealtad, las consecuencias son de diversa índole. Díaz (2015), al reseñarlas, se refiere a las de carácter indemnizatorio, conforme a las cuales los administradores responderán por los daños que causen por actos u omisiones realizados incumpliendo el aludido deber (artículo 236 (1) de la LSC); a las restitutorias, pues junto con la obligación de indemnizar el eventual daño causado al patrimonio social, también deberán devolver a la sociedad el "enriquecimiento injusto obtenido" (artículo 227 (2) de la LSC) y a las impugnatorias, toda vez que los actos $\mathrm{u}$ operaciones censuradas pueden ser objeto de acciones tendientes a que se declare su ineficacia (vid. art. 236 de la LSC).

Finalmente, es de resaltar el artículo 239 (1) de la LSC, conforme al cual la minoría tiene la posibilidad de ejercitar directamente la acción social de responsabilidad cuando los administradores infrinjan el deber de lealtad, sin necesidad de someter la decisión a la junta general, como respuesta al posible abuso de las mayorías, quienes en la mayor parte de los casos tienen a su cargo, en forma directa o indirecta, la administración de la sociedad. Sánchez-Calero (2015), al respecto apunta:

Esta solución subraya la importancia que el deber de lealtad ha pasado a cobrar en la nueva regulación, de manera que su infracción permite a la minoría una iniciativa tan excepcional como la de demandar a los administradores en defensa del interés social. La revisión del deber de lealtad ha querido dotar de especial vigencia su observancia y de mayor rigor a su infracción. Ante ésta, someter la iniciativa de la minoría 
en defensa de la sociedad a una previa junta general que rechace el acuerdo a favor de exigir responsabilidad aparecía como un obstáculo a remover. De ahí que se establezca una legitimación especial directa en atención al motivo de la acción social que la minoría puede entablar en defensa de la sociedad (p. 916).

\subsection{Chile}

En relación con el desarrollo del derecho societario en Chile, Vásquez (2015) señala:

[...] el Derecho de sociedades chileno dista de ser un cuerpo normativo unitario guiado bajo una lógica legislativa común, lo que se debe, sin lugar a dudas, al devenir histórico de los procesos legislativos, cuyas regulaciones han sido el producto de diversas necesidades puntuales que han afectado a la empresa o sociedad en particular. En tal sentido, en este Derecho se han construido diferentes figuras jurídicas, que responden a objetivos concretos de un momento dado (p. 80).

Durante el transcurrir de este proceso legislativo, en 2009 se promulgó y publicó la Ley 20382, sobre perfeccionamiento a los gobiernos corporativos de las empresas, la cual modificó la Ley 18045, Ley de Mercado de Valores (artículo 1); la Ley 18046, Ley de Sociedades Anónimas (artículo 2) y el Código de Comercio (artículo 3).

En punto del conflicto de intereses, la Ley 20382, al modificar la Ley 18046 (LSA), introdujo cambios en relación con la prevención de situaciones conflictivas, así como en los respectivos procedimientos para operaciones con partes relacionadas.

Si bien la LSA no brinda un concepto de conflicto de intereses, tampoco ampara los intereses individuales de los administradores, tal y como se desprende del artículo 42 (7), conforme al cual "los directores no podrán: [...] En general, practicar actos ilegales o contrarios a los estatutos o al interés social o usar de su cargo para obtener ventajas indebidas para sî o para terceros relacionados en perjuicio del interés social".

En relación con la prevención del conflicto de intereses, a través de la modificación del artículo 36 de la LSA, se incorporaron nuevos sujetos 
a los que se les prohíbe ser directores de "sociedades anónimas abiertas y sus filiales":

1) Los senadores, diputados y alcaldes;

2) Los ministros de Estado, subsecretarios, intendentes, gobernadores, secretarios regionales ministeriales, embajadores, jefes de servicio y el directivo superior inmediato que deba subrogar a cada uno de ellos, con excepción de los cargos de director de las sociedades anónimas abiertas en las que el Estado, según la ley, deba tener representantes en su administración, o sea accionista mayoritario, directa o indirectamente a través de organismos de administración autónoma, empresas fiscales, semifiscales, de administración autónoma, o aquellas en que el Estado sea accionista mayoritario;

3) Los funcionarios de las superintendencias que supervisen a la sociedad respectiva o a una o más de las sociedades del grupo empresarial a que pertenece, $\mathrm{y}$

4) Los corredores de bolsa y los agentes de valores, así como sus directores, gerentes, ejecutivos principales y administradores. Esta restricción no se aplicará en las bolsas de valores.

En punto de los representantes del gobierno y la administración del Estado, con las salvedades del caso, la razón de la prohibición es evitar la situación conflictiva que se puede generar en razón de la contraposición de roles de estas personas en atención a sus funciones, otorgando así mayor transparencia tanto al sector público como al sector privado. En lo que refiere a directores, gerentes, ejecutivos principales y administradores de corredores de bolsa y agentes de valores, la prohibición opera con la misma lógica, evitando, por ejemplo, que un gerente de una corredora recomiende, en ejercicio de su actividad, la adquisición de acciones de una sociedad en la que funge como director.

En virtud de las modificaciones legales que la Ley 20382 realizó a la LSA, se distingue el conflicto de intereses en operaciones con partes relacionadas, dependiendo de si se trata de una sociedad anónima abierta ${ }^{32}$

32 Conforme al artículo 2 de LSA, "son sociedades anónimas abiertas aquellas que inscriban voluntariamente o por obligación legal sus acciones en el Registro de Valores". 
o de una sociedad anónima cerrada ${ }^{33}$, por lo que se creó un nuevo Título XVI en la LSA que regula dichas transacciones para las primeras y se modificó el artículo 44, que se aplica solo a las segundas. De esta forma, no se prohíbe que un director pueda celebrar actos o contratos con la sociedad, sino que se reglamenta la materia a través de diversos procedimientos.

En el caso de sociedades anónimas cerradas, vía estatutaria se puede autorizar la realización de operaciones en que los directores tengan interés sin sujeción a las condiciones que señala el artículo 44 de la LSA. En cuanto a aquellas sociedades cuyos estatutos no contemplen la mentada autorización, Salas (2010) resume el procedimiento legal a cumplirse para que las transacciones puedan ser realizadas, así:

1) Se entrega un criterio general de operaciones de este tipo que deben cumplir con los estándares de la ley, acotándolo de manera expresa a aquellos actos o contratos que involucren montos relevantes ${ }^{34}$ en que uno o más directores tengan interés por sí o como representantes de otra persona.

2) Se mantiene el criterio que exige que dichas operaciones sean conocidas y aprobadas previamente por el directorio y que se ajuste a condiciones de equidad similares a las que habitualmente prevalecen en el mercado.

3) Se dispone una alternativa a la aprobación previa del directorio, en caso que la operación sea aprobada o ratificada por la junta extraordinaria de accionistas con el quórum de dos tercios de los accionistas con derecho a voto.

33 El artículo 2 de la LSA señala que "son sociedades anónimas cerradas las que no califican como abiertas o especiales", últimas reguladas en el Título XIII de la LSA, dentro de las cuales se cuentan, entre otras, las compañías aseguradoras y reaseguradoras, las sociedades anónimas administradoras de fondos mutuos y las bolsas de valores, sujetas disposiciones especiales (artículo 126 y siguientes).

34 En los términos del inciso 4 del artículo 44 de la LSA, "se entiende que es de monto relevante todo acto o contrato que supere el $1 \%$ del patrimonio social, siempre que dicho acto o contrato exceda el equivalente a 2000 unidades de fomento y, en todo caso, cuando sea superior a 20000 unidades de fomento. Se presume que constituyen una sola operación todas aquellas que se perfeccionen en un período de 12 meses consecutivos por medio de uno o más actos similares o complementarios, en los que exista identidad de partes, incluidas las personas relacionadas, u objeto". 
4) Se pasa de una presunción de derecho a una simplemente legal, respecto de las negociaciones, actos o contratos en que hay interés de un director (se mantienen idénticas las hipótesis ${ }^{35}$ ), de modo que este podrá acreditar lo contrario (p. 24).

En contraposición, en el caso de las sociedades anónimas abiertas, el procedimiento regulado en el incorporado Título XVI de la LSA (artículos 146 a 149) es más exhaustivo en cuanto a las operaciones con partes relacionadas. Al respecto, Salas (2010) expresa:

Respecto de las S.A. abiertas, el nuevo Título XVI de la LSA establece una regulación mucho más detallada. En primer lugar, y a diferencia de lo que ocurre con las cerradas, el conflicto de interés que se trata de precaver no es solo respecto de los directores y la sociedad, sino que se extiende a otras entidades o personas respecto de las cuales siempre que contraten con la sociedad constituirán una operación con parte relacionada. Dicha restricción se extiende incluso por 18 meses, respecto de personas que, habiendo estado relacionadas con la sociedad, han dejado de estarlo.

En cualquiera de esos casos, la operación solo podrá llevarse a cabo en el evento que tenga por objeto contribuir al interés social, se ajuste en precio, términos y condiciones a aquellas que prevalezcan en el mercado al momento de su aprobación y cumpla con los requisitos y procedimientos de información y autorización que se establecen al efecto (pp. 24-25).

De estos nuevos requisitos, se destaca la forma de aprobación, toda vez que no solo no votarán los directores con interés o participación en la operación, sino que cuando la mayoría del directorio esté interesado en la transacción, la operación debe ser aprobada por la unanimidad de

35 De conformidad con el inciso 3 del artículo 44 de la LSA, "existe interés de un director en toda negociación, acto, contrato u operación en la que deba intervenir en cualquiera de las siguientes situaciones: 1) él mismo, su cónyuge o sus parientes hasta el segundo grado de consanguinidad o afinidad; 2) las sociedades o empresas en las cuales sea director o dueño, directamente o a través de otras personas naturales o jurídicas, de un $10 \%$ o más de su capital; 3 ) las sociedades o empresas en las cuales alguna de las personas antes mencionadas sea director o dueño, directo o indirecto, del $10 \%$ o más de su capital, y 4) el controlador de la sociedad o sus personas relacionadas, si el director no hubiera resultado electo sin los votos de aquél o aquéllos". 
los directores no comprometidos o no inhabilitados para aprobar el acto o negocio. También se establece la posibilidad que la junta de accionistas apruebe la operación con el voto de dos tercios de las acciones con derecho a voto, caso en el cual el directorio deberá designar a un evaluador independiente, cuyo propósito es informar a la junta de accionistas acerca de la conveniencia de realizar o no la operación que se somete a decisión de la misma.

Se excluyen del procedimiento general, bastando la sola aprobación del directorio, operaciones con partes relacionadas que sean declaradas como habituales, de monto no relevante o que se realicen con filiales en las que la sociedad controle al menos un $95 \%$ de la propiedad.

Al margen de las sanciones que sean del caso, las infracciones a este nuevo régimen no afectan la validez de la transacción, pero la sociedad o los accionistas tienen el derecho de demandar de la persona relacionada trasgresora, tanto el reembolso en beneficio de la sociedad de una suma equivalente a los beneficios que la operación hubiera reportado a la contraparte relacionada como la correspondiente indemnización por los daños causados, por lo que el demandado tendrá que probar que la operación censurada se ajustó a los procedimientos legales establecidos para contratar con personas relacionadas.

\section{Conclusiones}

En el presente documento se abordó la temática relativa al conflicto de intereses en el régimen de administradores de sociedades comerciales, concretamente, la utilización en la legislación societaria colombiana del conflicto de intereses como "concepto jurídico indeterminado". En este sentido, el documento partió de una reconstrucción de la regulación sobre la materia vigente en el contexto societario, pudiéndose concluir que la actual normatividad resulta deficiente y confusa, lo cual afecta tanto a los administradores como a los operadores judiciales que deben examinar las actuaciones de estos profesionales en el ejercicio de sus funciones. En efecto, el artículo 23 de la Ley 222 de 1995 prohíbe a los administradores realizar actos respecto de los cuales exista conflicto de intereses, salvo autorización de la junta de socios o asamblea general de 
accionistas. En estos casos, el administrador deberá suministrar toda la información relevante para la toma de la decisión. La autorización previa, a cargo del máximo órgano social, podrá otorgarse siempre y cuando no se perjudiquen los intereses de la sociedad. No obstante el Decreto 1925 de 2009 -hoy compilado en el Decreto 1074 de 2015-, reglamentar parcialmente citado artículo 23, la forma en como nuestro sistema jurídico trata el conflicto de intereses es desafortunada, porque no puede eludirse que se trata de una cláusula excesivamente abierta que envuelve demasiada subjetividad, con los problemas que esto conlleva tanto a los administradores como a quienes deben juzgar sus actuaciones, según ha sido explicado, haciéndose necesario un régimen más detallado, que sirva de guía para la administración de las sociedades comerciales a través de herramientas legales de gobernabilidad, poniéndolo a tono con las necesidades empresariales y los imperativos de los negocios mercantiles contemporáneos.

Bajo el anterior panorama, los procesos de reforma legislativa al derecho de sociedades, incluido el colombiano, deben tener en cuenta las tendencias del derecho comparado, particularmente los cambios legislativos exitosos ocurridos en otras latitudes, procurando incorporarlos a nuestra estructura jurídica para atender las realidades del mercado.

Sin desconocer la complejidad que conlleva el trasplante de un modelo o esquema desarrollado en otro contexto jurídico, un proceso adecuado de adaptación en donde se identifique la utilidad de las instituciones a partir de un marco teórico y económico claro, puede contribuir a mejorar las perspectivas económicas de un país.

Así las cosas, de cara al proceso de modernización del derecho societario colombiano, en tiempos recientes, la Superintendencia de Sociedades se encontraba liderando una iniciativa de reforma al Derecho Societario colombiano a través del Proyecto de Ley 070 de 2015, por medio de la cual se establecen reglas en materia de sociedades y se adoptan otras disposiciones, el cual si bien no continúo con su trámite legislativo en el Congreso de la República, es importante en consideración a las propuestas allí formuladas, pues sirven como antecedente para futuros procesos de reforma legislativa. En esta iniciativa se proponían cambios sustanciales al estatuto de administradores introducido por la Ley 222 de 1995 en lo concerniente al fortalecimiento del deber de lealtad a 
través de la regulación del conflicto de intereses, modificaciones que se construyeron a partir del análisis del derecho comparado, evaluando la función de distintos instrumentos jurídicos, para determinar así su eficacia e implementación en nuestro medio, aprovechando los avances alcanzados en otros sistemas.

La influencia de las doctrinas y legislaciones extranjeras es patente en el desarrollo del régimen jurídico colombiano. En palabras de López (2015):

[...]no hay casi ninguna iniciativa legislativa de importancia en la Colombia de los últimos años (país donde ejerce como abogado el autor de estas líneas) que no haya estado influenciada por ideas extranjeras o comparadas: piénsese, por ejemplo, en el Código de Procedimiento Penal, en el esquema de 'justicia transicional' para lidiar con las responsabilidades del conflicto colombiano, en la ley de víctimas y de restitución de tierras, en las leyes de implementación del Tratado de Libre Comercio con Estados Unidos, en la ley estatutaria de habeas data, el debate sobre la reforma constitucional al fuero penal militar, la reforma tributaria y, en general, en un sinnúmero de iniciativas legales o administrativas (pp. 123-124).

De esta suerte, frente a la imperiosa necesidad de actualización frente al estatuto de administradores vigente, incluida la regulación del conflicto de intereses, el análisis de la experiencia comparada en procesos de reformas legislativas societarias se hace indispensable, pues entender las modificaciones realizadas en otras latitudes a partir de sus fundamentos y soluciones propuestas, permitirá incorporar a nuestra estructura legal las mejores experiencias.

\section{Referencias}

Arrubla, J. A. (2012). Contratos mercantiles. Teoría general del negocio mercantil. Bogotá: Pontificia Universidad Javeriana \& Legis.

Barrero, A. (2011). Manual para el establecimiento de sociedades. Bogotá: Librería Ediciones del Profesional. 
Bernet, M. A. (2007). El deber de lealtad de los directores y los contratos en conflicto de interés. Revista Chilena de Derecho Privado (8), 107-153. Recuperado de http://www.redalyc.org/pdf/3708/370840820003.pdf

Blanco, C. (2013). La planificación del desarrollo: iproblema económico, político o jurídico? Opinión Jurídica 12 (24), 169-187. Recuperado de http://revistas. udem.edu.co/index.php/opinion/issue/view/67

Buitrago, J. P. (2013). Mecanismos para la resolución de situaciones constitutivas de conflictos de interés en el mercado de valores colombiano. Análisis - Revista del Mercado de Valores (4), 57-82. Recuperado de http://www.amvcolombia. org.co/index.php?pag=homeGid=35|141|0

Colombia, Congreso de la República. Ley 222/1995, por la cual se modifica el Libro II del Código de Comercio, se expide un nuevo régimen de procesos concursales y se dictan otras disposiciones (20 de diciembre de 1995).

Colombia, Consejo de Estado, Sala de lo Contencioso Administrativo, Sección Segunda, Subsección B. Sentencia 11001-03-25-000-2008-00116-00 (255608) (17 de mayo de 2012).

Colombia, Consejo de Estado, Sala de lo Contencioso Administrativo, Sección Segunda, Subsección B. Sentencia 08001-23-31-000-2010-00135-01 (157512) (20 de marzo de 2013).

Colombia, Corte Constitucional, Sala Plena. Sentencia C-651 (3 de diciembre de 2007).

Colombia, Corte Constitucional, Sala Plena. Sentencia C-123 (22 de febrero de 2006).

Colombia, Corte Constitucional, Sala Octava de Revisión. Sentencia T-450 (26 de mayo de 2011).

Colombia, Presidencia de la República, Ministerio de Justicia. Decreto 410/1971, por el cual se expide el Código de Comercio (27 de marzo de 1971).

Colombia, Presidencia de la República, Ministerio de Comercio, Industria y Turismo. Decreto 1925/2009, por medio del cual se reglamenta parcialmente el artículo 23 de la Ley 222 de 1995, y demás normas concordantes, en lo relativo a conflictos de interés y competencia con la sociedad por parte de los administradores de la sociedad (28 de mayo de 2009).

Colombia, Presidencia de la República, Ministerio de Comercio, Industria y Turismo. Decreto 1074/2015, por medio del cual se expide el Decreto Único Reglamentario del Sector Comercio, Industria y Turismo (26 de mayo de 2015).

Colombia, Superintendencia de Sociedades, Delegatura para Procedimientos Mercantiles. Sentencia 800-54 (14 de mayo de 2015). 
Chile, Ministerio de Hacienda. Ley 18.046 sobre sociedades anónimas (22 de octubre de 1981).

Chile, Ministerio de Hacienda. Ley 20.382, que introduce perfeccionamientos a la normativa que regula los gobiernos corporativos de las empresas (20 de octubre de 2009).

Córdoba, P. A. (2014). El derecho de sociedades y el gobierno de la sociedad anónima: el interés social, órganos, accionistas y administradores. Bogotá: Universidad Externado de Colombia.

Cuif, P.F. (2007). El conflicto de intereses. Ensayo sobre la determinación de un principio jurídico en derecho privado. Revista de Derecho Privado (12-13), 55-93. Recuperado de http://revistas.uexternado.edu.co/index.php/derpri/ issue/view/61

Delvasto, C. A. (2007). La representación legal de las sociedades comerciales en Colombia y el problema de principal y agente. Soluciones. Criterio Jurídico (7), 295-322. Recuperado de http://revistas.javerianacali.edu.co/index.php/ criteriojuridico/issue/view/25

Díaz, A. (2015). Deber de lealtad y conflictos de intereses (observaciones al hilo del régimen de las operaciones vinculadas). En Gómez-Acebo \& Pombo (Ed.), Las reformas del régimen de sociedades de capital según la Ley 31/2014 (pp. 28-34). España: Comunicación Impresa, S. L. Recuperado de http://www. gomezacebo-pombo.com/index.php/es/conocimiento/libros/item/1942-lasreformas-del-régimen-de-sociedades-de-capital-según-la-ley-31-2014

España, Ministerio de la Presidencia. Real Decreto Legislativo 1/2010 por el cual se aprueba el texto refundido de la Ley de Sociedades de Capital (2 de julio de 2010).

España, Jefatura del Estado. Ley 31/2014 por la que se modifica la Ley de Sociedades de Capital para la mejora del gobierno corporativo (3 de diciembre de 2014).

Estados Unidos, American Bar Association, Committee on Corporate Laws of the Section of Business Law. The Revised Model Business Corporation Act (2016 Revision).

Estados Unidos, State of Delaware. Delaware General Corporation Law.

Gaitán, A. (2011). Grupos empresariales y control de sociedades en Colombia. Bogotá: Superintendencia de Sociedades.

Galgano, F., Roitman, H., León, E. I., E López, Y. (2012). Los Grupos Societarios. Dirección y coordinación de sociedades. Bogotá: Universidad del Rosario.

Gaviria, J. A. (2005). Retos del derecho de grupos societarios en el siglo XXI. Foro de Derecho Mercantil, Revista Internacional (9), 87-119. 
Gaviria, E. (2002). Nuevo Régimen de Sociedades. Comentario General. Medellín: Biblioteca Jurídica Diké.

Gaviria, E. (2004). Apuntes sobre el Derecho de las Sociedades. Medellín: Señal Editora. Gil, J. H. (2015). La especial responsabilidad del administrador societario. Bogotá: Legis. Isaza, A. E Londoño, A. (2011). Comentarios al Régimen de Insolvencia Empresarial. Bogotá: Legis.

Jurfest, S. P., Paredes, R. D., E Riutort, J. (2015). Tomas de control en el mundo y beneficios privados del control bajo las distintas regulaciones vigentes. $E l$ Trimestre Económico LXXXII, 4(328), 847-871. Recuperado de http://www. redalyc.org/articulo.oa?id $=31343926004$

López, D. E. (2015). El nacimiento del derecho comparado moderno como espacio geográfico y como disciplina: instrucciones básicas para su comprensión y uso desde América Latina. International Law, Revista Colombiana de Derecho Internacional, 13(26), 117-159. Recuperado de http://diegolopezmedina. net/wp-content/uploads/2014/03/Diego-López-Medina-El-nacimiento-delderecho-comparado-moderno.-International-Law-Vol.-13-Num.-26-2015.pdf

Martínez, N. H. (2004). Cátedra de derecho bancario colombiano. Bogotá: Legis.

Martínez, N. H. (2014). Cátedra de Derecho Contractual Societario. Regulación comercial y bursátil de los actos y contratos societarios. Bogotá: Legis.

Medina, J. (2015). Responsabilidad Comercial. De las sociedades y sus vinculados. Bogotá: Temis.

Mendoza, J. M. (2015). Reforma al régimen de los administradores sociales. En Superintendencia de Sociedades (Ed.), Proyecto de reforma al régimen societario 2015 (pp. 39-69). Bogotá: Imprenta Nacional de Colombia. Recuperado de http://www.supersociedades.gov.co/noticias/Documents/2015/Septiembre/ Libro\%20proyecto\%20de\%20reforma.pdf

Miguens, H. J. (2010). El deber de diligencia de los directores societarios en los Estados Unidos. Foro de Derecho Mercantil, Revista Internacional (29), 65-93.

Morgestein, W. I. (2011). El Concepto de Interés Social y su Impacto en el Derecho de Sociedades Colombiano. e-Mercatoria 10 (2), 1-21. Recuperado de http://www.emercatoria.edu.co/PAGINAS/volumen 10/02.html

Navarro, L. (2014). Evoluciones recientes en Derecho societario europeo y español. Foro de Derecho Mercantil, Revista Internacional (44), 59-79.

Nuñez, M. (2013). Los conceptos jurídicos indeterminados: la mercadería. Controversias y soluciones. Quito: Universidad Andina Simón Bolívar \& Corporación Editora Nacional. Recuperado de http://repositorio.uasb.edu.ec/ bitstream/10644/4038/1/SM132-Nu\%C3\%B1 ez-Los\%20conceptos.pdf 
Peña, L. (2014). De las sociedades comerciales. Bogotá: Ecoe Ediciones \& Universidad del Sinú.

Pereira, R. (2015). Derecho Concursal. Régimen de insolvencia empresarial. Bogotá: Leyer.

Pinzón, G. (1982). Sociedades Comerciales. Teoría General. Volumen I. Bogotá: Temis.

Posada, J. A. (2008). Una visión desde el Derecho Comparado y el Análisis Económico del Derecho de la estructura societaria en Latinoamérica. Estudios de Derecho 66 (146), 111-145. Recuperado de http://aprendeenlinea.udea. edu.co/revistas/index.php/red/article/view/2400

Rengifo, R. (2012). Personas jurídicas de derecho privado (Sociedades). Medellín: Señal Editora.

Reyes, F. (2010). Responsabilidad de los administradores en la sociedad por acciones simplificada. En F. Reyes Villamizar (Coord.), Estudios sobre la sociedad por acciones simplificada (pp. 177-246). Bogotá: Universidad Externado de Colombia.

Reyes, F. (2013a). Análisis Económico del Derecho Societario. Bogotá: Legis.

Reyes, F. (2013b). SAS La Sociedad por Acciones Simplificada. Bogotá: Legis.

Reyes, F. (2013c). Derecho Societario en Estados Unidos y la Unión Europea. Bogotá: Legis.

Reyes, F. (2016). Derecho Societario. Tomo I. Bogotá: Temis.

Rodríguez, J. J. (2015). Régimen de insolvencia de la persona natural no comerciante. Bogotá: Universidad Externado de Colombia.

Sabogal, L. F. (2011). El "Interés Social": Apuntes Teóricos en el Marco SocioEconómico del Derecho de Empresa. e-Mercatoria 10 (1), 1-25. Recuperado de http://www.emercatoria.edu.co/PAGINAS/VOLUMEN10/01.html\#a114

Sabogal, L. F. (2014). La responsabilidad de los administradores por conflictos de interés en la empresa de grupo. e-Mercatoria 13 (2), 1-26. Recuperado de http://www.emercatoria.edu.co/PAGINAS/volumen13/02.html\#a171

Salas, J. (2010). Nueva Normativa sobre Gobiernos Corporativos: Un Análisis. Informe Legislativo (30), 1-28. Recuperado de http://lyd.org/wp-content/ themes/LYD/files_mf/SIL-30-Nueva-Normativa-sobre-Gobiernos-Corporativos-Un-analisis-JSalas-Marzo2010.pdf

Sánchez-Calero, J. (2015). La reforma de los deberes de los administradores y de su responsabilidad. En M. J. Morillas, P. Perales Viscasillas \& L. J. Porfirio Carpio (Dir.), Estudios sobre el futuro Código Mercantil, Libro Homenaje al Profesor Rafael Illescas Ortiz (pp. 894-917). Madrid: Universidad Carlos III de Madrid. Recuperado de http://e-archivo.uc3m.es/handle/10016/20763 
Santos, J. (2012). Responsabilidad Civil. Tomo 11. Bogotá: Pontificia Universidad Javeriana \& Temis.

Uribe, N. (2013). El régimen general de responsabilidad civil de los administradores de sociedades y su aseguramiento. Bogotá: Pontificia Universidad Javeriana \& Grupo Editorial Ibañez.

Vásquez, M. F. (2015). ¿Hacia dónde va el Derecho Societario?: Un análisis desde el Derecho Comparado y una propuesta preliminar para el Derecho Chileno. Revista Chilena de Derecho 42 (1), 57-91. Recuperado de http:// www.redalyc.org/articulo.oa?id=177039318004

Vélez, L. G. (2011). Una breve historia del derecho concursal moderno en Colombia. Revista Superintendencia de Sociedades (1), 4-9. Recuperado de http:// www.supersociedades.gov.co/prensa/publicaciones/Paginas/Revistas.aspx 